Archive for

Organic Chemistry

Arkivoc 2020, part iii, 74-89

\title{
Synthesis, structural elucidation, intramolecular hydrogen bonding and DFT studies of quinoline-chalcone-chromene hybrids
}

\author{
Lamla Thungatha, Saba Alapour, and Neil A. Koorbanally*
}

School of Chemistry and Physics, University of KwaZulu-Natal, Private Bag X54001, Durban, 4001, South Africa Email: Koorbanally@ukzn.ac.za

Received 03-12-2020

Accepted 07-31-2020

Published on line $08-12-2020$

\section{Abstract}

Eight hydroxyquinoline-chromene chalcones, of which six were new, were synthesized using the VilsmeierHaack reaction and Claisen-Schmidt condensation. These contain either mono or dichromene functionality. The hydroxyl proton chemical shift of both types of compounds at varying temperature indicated weakened hydrogen bonds with an increase in temperature, however there was no significant difference to the slopes of the $\mathrm{OH}$ chemical shift curves $\left(3.4 \times 10^{-3}\right.$ for the 2-methoxychromene derivative and $3.1 \times 10^{-3}$ for the 6 methoxydichromene derivative. Potential energy scans of these two compounds were obtained using B3LYP/6-311 G level theory in the gas phase, and showed the enol form to be most stable for both molecules and that the energy barrier to make proton transfer possible is 5.076 and $3.989 \mathrm{Kcal} \mathrm{mol}^{-1}$ for the 2methoxychromene and 6-methoxydichromene derivatives respectively.<smiles>CC(=O)c1ccc2c(c1O)C=CC(C)(C)O2</smiles><smiles>[R]c1ccc2nc([R])c(C=O)cc2c1</smiles>

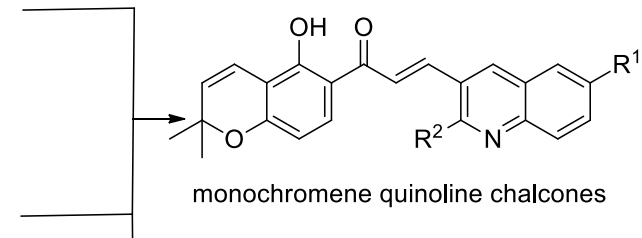<smiles>CC(=O)c1c(O)c2c(c3c1C=CC(C)(C)O3)OC(C)(C)C=C2</smiles><smiles></smiles>

dichromene quinoline chalcones 


\section{Introduction}

Quinoline is a heterocyclic aromatic organic molecule with a broad spectrum of pharmacological properties including antimalarial, ${ }^{1}$ antibacterial, ${ }^{2-3}$ antifungal, ${ }^{4}$ anticancer, ${ }^{5}$ antitubercular, ${ }^{6}$ antileishmanial ${ }^{7}$ and anti- $^{2}$ inflammatory. ${ }^{8}$ Current pharmaceuticals containing this pharmacophore include Amodiaquine, Chloroquine, Ciprofloxacin, Levofloxacin and Mefloquine. These drugs have a quinoline core hybridised with other pharmacophores leading to more potent drugs. Quinoline molecules substituted at C-3 are also known for their broad range of biological activities. These hybrid molecules include quinoline chalcones synthesised from 3-quinoline carbaldehydes and have shown promising anticancer, ${ }^{5}$ antibacterial ${ }^{9}$ and antiprotozoal ${ }^{10}$ activities. Quinoline chalcones are also used as precursors for bioactive quinoline pyrazole derivatives. ${ }^{11}$

Benzopyran on the other hand, consists of a benzene ring fused to a pyran ring and is mostly found in natural products. They show a broad range of biological activities, such as anticancer ${ }^{12}$ and anti-inflammatory activity. ${ }^{13}$ This scaffold also forms part of the flavones, potent antioxidants and known to have good biological activity. $^{14}$

Derivatives of ortho-hydroxy acetophenone, used to synthesise chalcones are known to have intramolecular hydrogen bonding (IHB) and intramolecular proton transfer (IPT) properties. ${ }^{15}$ Intramolecular proton transfer is also known to be enhanced by photoexcitation of the molecule. This concept is known as the excited state intramolecular proton transfer (ESIPT) and was first studied by Albert Weller. ${ }^{16}$ IHB and IPT or ESIPT have since been extensively studied both theoretically and experimentally. ${ }^{17}$ The two phenomena occur by interaction of the oxygen atom of the carbonyl group $\mathrm{C}=\mathrm{O}$ and the hydrogen atom of the hydroxy group in 2-hydroxyacetophenones. IHB and ESIPT are known to affect the physical properties of the molecule as well as their bioactivity, photochemistry and reactivity, which differ depending on the properties of the molecular subunits or core structure. ${ }^{18-20}$ The chalcones reported in this work have a hydroxyl group on the chromene core adjacent to the carbonyl carbon of the chalcone.

The hydrogen bond is an important intermolecular interaction in biochemical processes. ${ }^{21} \mathrm{NMR}$ chemical shifts are very sensitive to steric, electronic effects, and molecular interactions. ${ }^{22}$ It is therefore a good tool to identify and study hydrogen bond interactions. Hydrogen bonds are classified in two different groups, strong and weak hydrogen bonds. Strong hydrogen bonds are those in which hydrogen is covalently bound to $\mathrm{N}, \mathrm{O}$, or $\mathrm{F}$ and form a second weak interaction to another electronegative atom $(\mathrm{N}, \mathrm{O}$, or $\mathrm{F}) .{ }^{23}$ Weak hydrogen bonding is when hydrogen is attached to a $\mathrm{sp}^{\mathrm{x}}(\mathrm{x}=1-3)$ hybridized carbon and forms additional weak interactions with electronegative atoms. ${ }^{24-25}$ In a weak hydrogen bond, the hydrogen bond donor must be electron deficient enough to be attracted to an electron-rich atom. ${ }^{25}$

We herein report the synthesis of quinoline chromenochalcone hybrid molecules, their structural elucidation by NMR, and a study of the hydrogen bonding using VT NMR. DFT studies, carried out to understand the electronic properties of the molecule are also reported.

\section{Results and Discussion}

The quinoline-3-carbaldehyde intermediates (1) were synthesised in three steps using the Vilsmeier-Haack reaction where $\mathrm{POCl}_{3}$ and DMF were reacted with acetanilides (Scheme 1). ${ }^{26-28}$ The chromene derivatives were made in a single step, which involved reaction of 2,4-dihydroxy or 2,4,6-trihydroxyacetophenone with 3methylcrotonaldehyde to form the desired monochromene (2) or dichromene (3) acetophenone derivatives. 
The final step involved reaction of the quinoline-3-carbaldehydes with the chromeno acetophenones using the Claisen-Schmidt condensation ${ }^{29}$ to synthesise quinoline chromenochalcone hybrids (4).

The Vilsmeier-Haack reaction works better in dry conditions and the Claisen-Schmidt condensation does not work well with some hydroxyacetophenones, ${ }^{30-31}$ indicated by the low yields of $4 \mathbf{a}-\mathbf{h}$ (38-46\%). This can be attributed to the competing enolate ion and phenoxide ion of the hydroxyacetophenone arising from the base abstraction of both the $\alpha$ proton and hydroxy proton of the acetophenone. ${ }^{32}$<smiles>CC(=O)c1ccc(O)cc1O</smiles><smiles>[V]C1CCCCC1</smiles><smiles>[R]CCCCCCCC(C)=O</smiles><smiles>[R]c1ccc2nc([R])c(/C=C/C(=O)c3ccc4c(c3O)C=CC(C)(C)O4)cc2c1</smiles>

4a-d

$4 a: R^{1}=H, R^{2}=C l$

4b: $R^{1}=H, R^{2}=$ OMe

$4 c: R^{1}=M e, R^{2}=C l$

$4 d: R^{1}=M e, R^{2}=$ OMe<smiles>[R]c1ccc(N)cc1</smiles>

(i), (ii)

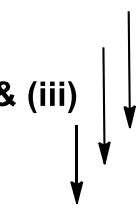<smiles>CC(=O)c1c(O)cc(O)cc1O</smiles>

(v)<smiles>[Z1]c1ccc2c(c1)cc(C(=O)c1c(O)c3c([n+](C)c1[R])OC(C)(C)C=C3)c1c3c(c(C(C)=O)c(O)c12)OC(C)(C)C=C3</smiles>

(vi)<smiles>[R]c1ccc2nc([R])c(/C=C/C(=O)c3c(O)c4c(c5c3OC(C)(C)C=C5)OC(C)(C)C=C4)cc2c1</smiles>

$$
\begin{aligned}
& \text { 4e: }: R^{1}=H, R^{2}=C l \\
& \mathbf{4 f}: R^{1}=H, R^{2}=O M e \\
& 4 \mathbf{g}: R^{1}=M e, R^{2}=C l \\
& 4 \mathbf{h}: R^{1}=M e, R^{2}=O M e
\end{aligned}
$$

Scheme 1. Synthetic scheme to quinoline chromenochalcones. (i) Acetic anhydride, $6 \mathrm{~h}$; (ii) $\mathrm{DMF}, \mathrm{POCl}_{3}, 80{ }^{\circ} \mathrm{C}$, $18 \mathrm{~h}$; (iii) $\mathrm{MeOH}, \mathrm{KOH}$ reflux; (iv) 3-methylcrotonaldehyde (1 eq.), pyridine, $150{ }^{\circ} \mathrm{C}, 12 \mathrm{~h}$; (v) 3methylcrotonaldehyde (2 eq.), pyridine, $150{ }^{\circ} \mathrm{C}, 12 \mathrm{~h}$; (vi) $\mathrm{KOH}, \mathrm{EtOH}, \mathrm{rt}, 48 \mathrm{~h}$.

Characteristic resonances for all chalcones were observed. For example in $\mathbf{4 f}$, the two doublets for $\mathrm{H}-\mathbf{9}$ and $\mathrm{H}-10$ occured at $\delta 7.97$ and 8.27 respectively with large coupling constants of $15.8 \mathrm{~Hz}$, an indication of trans coupled alkene protons. The formation of these compounds was also confirmed by HMBC correlations of $\mathrm{H}-9$ to $\mathrm{C}-2$ and $\mathrm{C}-4$, and $\mathrm{H}-10$ to $\mathrm{C}-3$. The $\alpha, 6$-unsaturated carbonyl resonance occurred at $\delta 193.1$. The chromene rings are characterised by a pair of doublets for each ring $\left(\mathrm{H}-10^{\prime}\right.$ and $\mathrm{H}-11^{\prime}$ at $\delta 5.47$ and $\delta 6.61$, and $\mathrm{H}^{\prime} 3^{\prime}$ and

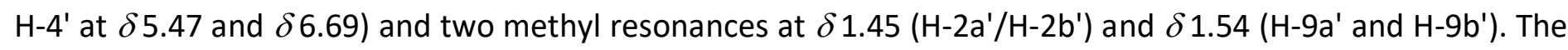
resonances for each of the pairs of olefinic protons in the chromene rings were paired in the COSY spectrum. 
Furthermore, $\mathrm{H}-9 \mathrm{a}^{\prime}$ and $\mathrm{H}-9 \mathrm{~b}^{\prime}$ showed $\mathrm{HMBC}$ correlations to $\mathrm{C}-10 \mathrm{C}$, and $\mathrm{H}-2 \mathrm{a}^{\prime}$ and $\mathrm{H}-2 \mathrm{~b}^{\prime}$ showed HMBC correlations to C-3'. H-4' and $\mathrm{H}-3^{\prime}$ showed $\mathrm{HMBC}$ correlations to C-8a' and C-4a' respectively (Figure 1). The hydroxyl proton $\mathrm{H}-5 \mathrm{a}^{\prime}$ also showed a correlation to $\mathrm{C}-4 \mathrm{a}^{\prime}$ confirming the assignment of this system. Both methyl resonances of the chromene ring adjacent to the hydroxyl group showed NOESY correlations to the hydroxyl proton H-5a'.

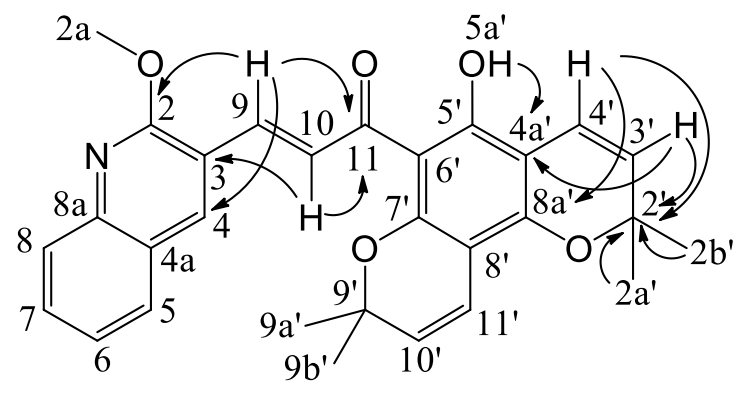

Figure 1. Selected HMBC correlations for $\mathbf{4 f .}$

The proton resonances of $\mathrm{H}-4$ to $\mathrm{H}-8$ on the quinoline ring were observed to be more deshielded when a chloro group was substituted at C-2 than when a methoxy group was substituted at the same position. This is attributed to the more electronegative chloro group, withdrawing electron density from the quinoline ring as opposed to the electron donating methoxy group. With the hydroxy proton 5a', the opposite occurs. Compounds with a chloro group have a more shielded proton resonance for $\mathrm{H}-5 \mathrm{a}$ ' than those compounds with a chloro group. This is indicative of slightly weaker hydrogen bonding between the hydroxy group and carbonyl group of the $\alpha, b$-unsaturated moiety (the stronger the hydrogen bonding, the more deshielded the resonance is) as opposed to when a methoxy is situated at the same position. This is possibly due to the slightly shorter $\mathrm{C}=\mathrm{O}$ bond due to the electronegative chloro group. As usual, the 8 proton, $\mathrm{H}-9$ in the chalcone moiety is more deshielded than $\mathrm{H}-10$ due to resonance effects. ${ }^{33}$ These correlations are later confirmed in the $3 \mathrm{D}$ crystal and DFT optimised structures. The ${ }^{13} \mathrm{C}$ NMR data is fairly consistent across the series of compounds.

The synthesised compounds formed crystals by slow evaporation in a solution of ethanol. Single crystal Xray diffraction data for $\mathbf{4 b}$ and $\mathbf{4} \mathbf{f}$ (with atom numbering shown in Figure $\mathbf{2}$ below) show that $\mathbf{4 b}$ is monoclinic and $\mathbf{4 f}$ triclinic with space group $\mathrm{P} 21 / \mathrm{n}$ and $\mathrm{P}-1$ respectively. In $\mathbf{4 b}$, an intramolecular hydrogen bond is observed between the hydroxyl proton $\mathrm{H} 2$ and the carbonyl oxygen $\mathrm{O} 3(1.754 \AA)$ and between the same atoms in $\mathbf{4 f}$ between $\mathrm{H} 2$ and $\mathrm{O} 5$ (1.708 $\AA$ ) (Figures 2 and 3). The reason for the stronger hydrogen bond when a second ring is added to the structure is not known, but could involve the additional oxygen present in $\mathbf{4 f}$. Intermolecular hydrogen bonds are also observed with the methyl groups, nitrogen in the quinoline ring and oxygen in the hydroxy and methoxy groups and in the chromene ring (Table 1 ). In $\mathbf{4 b}$, the monochromeno chalcone (Figure 2), the quinoline ring is situated with the methoxy group (O4-C24) and the nitrogen (N5) trans to the carbonyl group (C12-O3). This situates the two electronegative oxygen atoms as far apart as possible. However, in $\mathbf{4 f}$, the dichromenochalcone (Figure 3), the quinoline ring rotates itself $180^{\circ}$ (compared to $4 \mathbf{b}$ ) around the $\mathrm{C} 9-\mathrm{C} 10$ bond, due to steric hindrance, so as to move out of the way of the dimethyl groups (C-29 and C-30) and the pyran oxygen (O4) in the angular pyran ring. The methoxy group (O3-C22) and nitrogen (N1) is now situated cis to the carbonyl group (C7-O5). 
Table 1. Intermolecular hydrogen bonds for $\mathbf{4 b}$ and $\mathbf{4 f}$

\begin{tabular}{llll}
\hline Compound 4b & & Compound $\mathbf{4 f}$ \\
D-H...A & $d(H \ldots A) / \AA$ & D-H...A & $d(H \ldots A)$ \\
\hline $\mathrm{C}(24)-\mathrm{H}(24 b) \ldots \mathrm{O}(1)$ & 2.561 & $\mathrm{C}(1)-\mathrm{H}(1 \mathrm{c}) \ldots \mathrm{N}(1)$ & 2.694 \\
$\mathrm{C}(4)-\mathrm{H}(4) \ldots \mathrm{O}(3)$ & 2.715 & $\mathrm{C}(15)-\mathrm{H}(15 \mathrm{a}) \ldots \mathrm{N}(1)$ & 2.704 \\
$\mathrm{C}(2)-\mathrm{H}(2 \mathrm{~b}) \ldots \mathrm{O}(3)$ & 2.704 & $\mathrm{C}(29)-\mathrm{H}(29 \mathrm{a}) \ldots \mathrm{O}(5)$ & 2.484 \\
& & $\mathrm{C}(29)-\mathrm{H}(29 \mathrm{~b}) \ldots \mathrm{O}(2)$ & 2.680 \\
& & $\mathrm{C}(30)-\mathrm{H}(30 \mathrm{c}) \ldots \mathrm{O}(3)$ & 2.526 \\
\hline
\end{tabular}
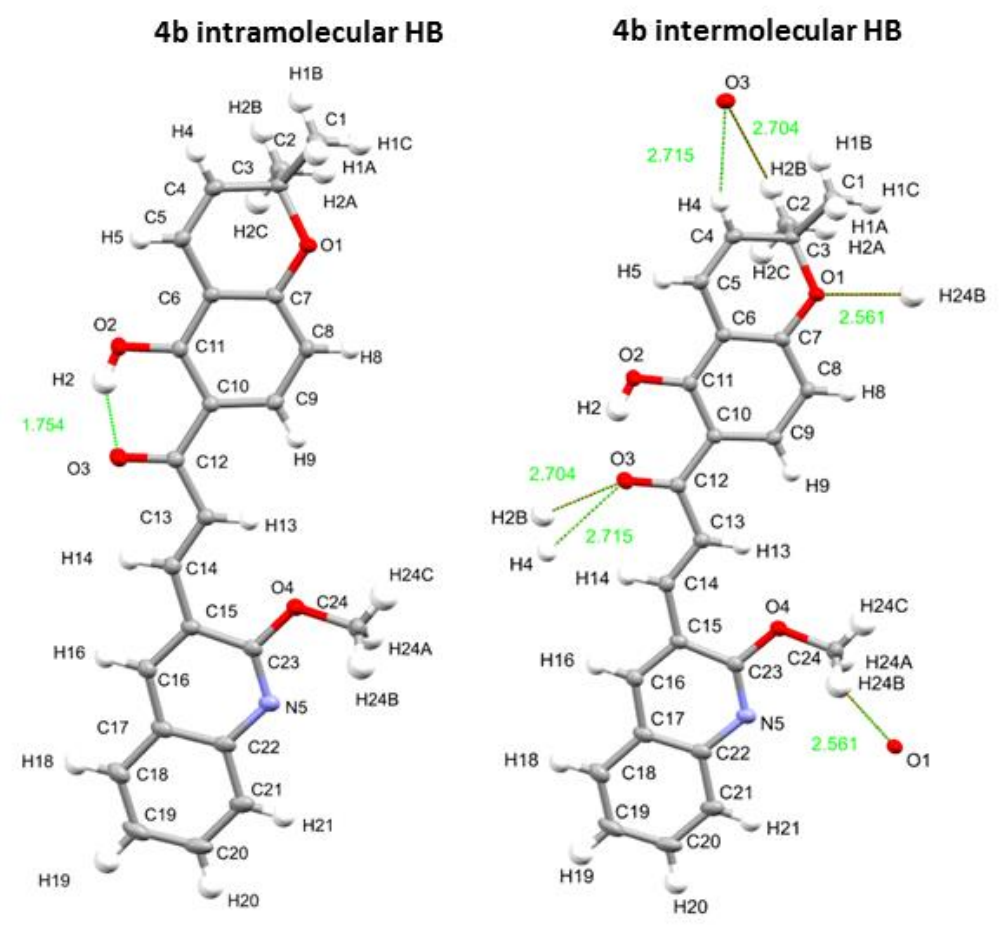

Figure 2. Intramolecular and intermolecular hydrogen bonds for $\mathbf{4 b .}$ 

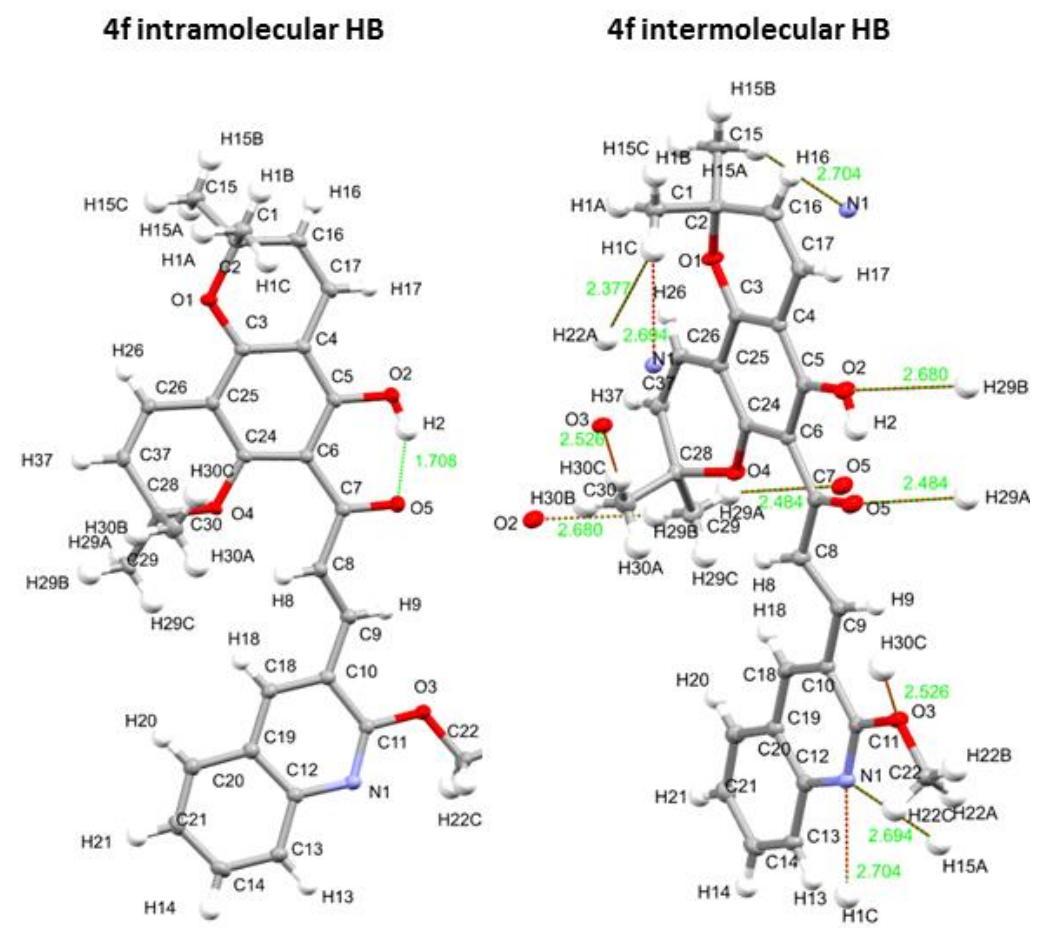

Figure 3. Intramolecular and intermolecular hydrogen bonds for $\mathbf{4 f}$.

\section{Variable Temperature NMR studies}

Hydrogen bonding of the $\mathrm{O}-\mathrm{H}$ proton $\mathrm{H}-5 \mathrm{a}$ ' (Figure 1) with the carbonyl oxygen at $\mathrm{C}-11$ was indicated by the downfield chemical shift between $\delta$ 13.47-14.30, and further suggested by a broad $\mathrm{O}-\mathrm{H}$ stretching band at 2489-2637 $\mathrm{cm}^{-1}$ in the IR spectrum. Compounds $\mathbf{4 b}$ with a single pyran ring and $\mathbf{4 f}$ with two pyran rings were selected to study the strength of the hydrogen bond at different temperatures. Compound $\mathbf{4 f}$ with an $\mathrm{O}-\mathrm{H}$ chemical shift at $\delta 14.30$ at room temperature was more deshielded than $\mathbf{4 b} \delta 13.68$ indicating that the extra pyran ring affected hydrogen bonding in some way. The strength of the hydrogen bond in solution can be determined by chemical shift variation of a proton in the hydrogen bond donor. ${ }^{23,34}$

The chemical shift of the $\mathrm{O}-\mathrm{H}$ proton decreased linearly with increasing temperature for both compounds indicating weakening of hydrogen bond interactions with increasing temperature (Figure S40). However, the slopes of the two compounds $4 \mathbf{b}\left(3.4 \times 10^{-3} \mathrm{ppm} / \mathrm{K}\right)$ and $4 \mathrm{f}\left(3.1 \times 10^{-3} \mathrm{ppm} / \mathrm{K}\right)$ did not show a significant difference, $13.47-13.70 \mathrm{ppm}$ for $\mathbf{4 b}$ and $14.10-14.30 \mathrm{ppm}$ for $\mathbf{4 f}$. This indicates that this hydrogen bond in both compounds were fairly strong and not disrupted by additional heat.

In $\mathbf{4 b}$, the $\mathrm{H}-\mathbf{9}$ chemical shift decreases (becomes more shielded) non-linearly with an increase in temperature (Figure S12), due to a weakening of the $\mathrm{H}$ bond. The opposite is observed in $4 \mathbf{f}$ (Figure S36), where the quinoline ring is rotated $180^{\circ}$ around the C3-C9 bond compared to $\mathbf{4 b}$ (Figure 1 ). In this case, an increase in chemical shift is experienced with increase in temperature, due to H-9 being in close proximity to both the oxygen atoms of the methoxy and carbonyl groups.

\section{Frontier molecular orbitals and photophysical properties of the molecule}

Good agreement in bond lengths and angles between the single crystal X-ray data and DFT calculations were observed. This indicated that theoretical calculations were a good approximation of the observed values. It also indicated that solid and gas phase structures are similar. HOMO-LUMO energy values and their band gaps 
were obtained for structures 4a-h (Figure 4). The charge distribution of frontier molecular orbitals follows the same trend. Essentially, the HOMO electron density is mostly distributed on the chromene or dichromene core and the LUMO electron density on the quinoline core and partially on the benzene ring of the chromene or dichromene core. The band gaps of the chromene derivatives (4a-4d) are observed to be higher $\sim 3.2 \mathrm{eV}$ compared to the dichromene derivatives $(\mathbf{4 e}-\mathbf{4 h})$, which is $\sim 2.9 \mathrm{eV}$. Band gaps are known to be related to stability of the molecule. The larger the band gap, the more stable the molecule, indicating the greater stability of the chromene derivative over their dichromene counterparts.

Molecular electrostatic potential (MEP) maps assigns electrostatic potential on each atom of the molecule. This phenomenon correlates with dipole moment, electronegativity and partial charges, ${ }^{35}$ and makes it possible to identify reactive sites of a molecule toward nucleophiles and electrophiles. One can also see how charge distribution of the molecule can affect inter- and intramolecular interactions. The red shaded portions indicate negative regions, reactive to electrophiles and the blue shaded portions are positive, reactive to nucleophiles. ${ }^{36}$ Figure 5 shows that the 2-hydroxy and carbonyl oxygen atoms are the most electronegative, being the best electron bond acceptors in the molecule. This results in intramolecular hydrogen bonding between the $\mathrm{O}-\mathrm{H}$ proton and carbonyl group oxygen and intermolecular hydrogen bonding between the $\mathrm{O}-\mathrm{H}$ oxygen and hydrogen bond donors in adjacent molecules.

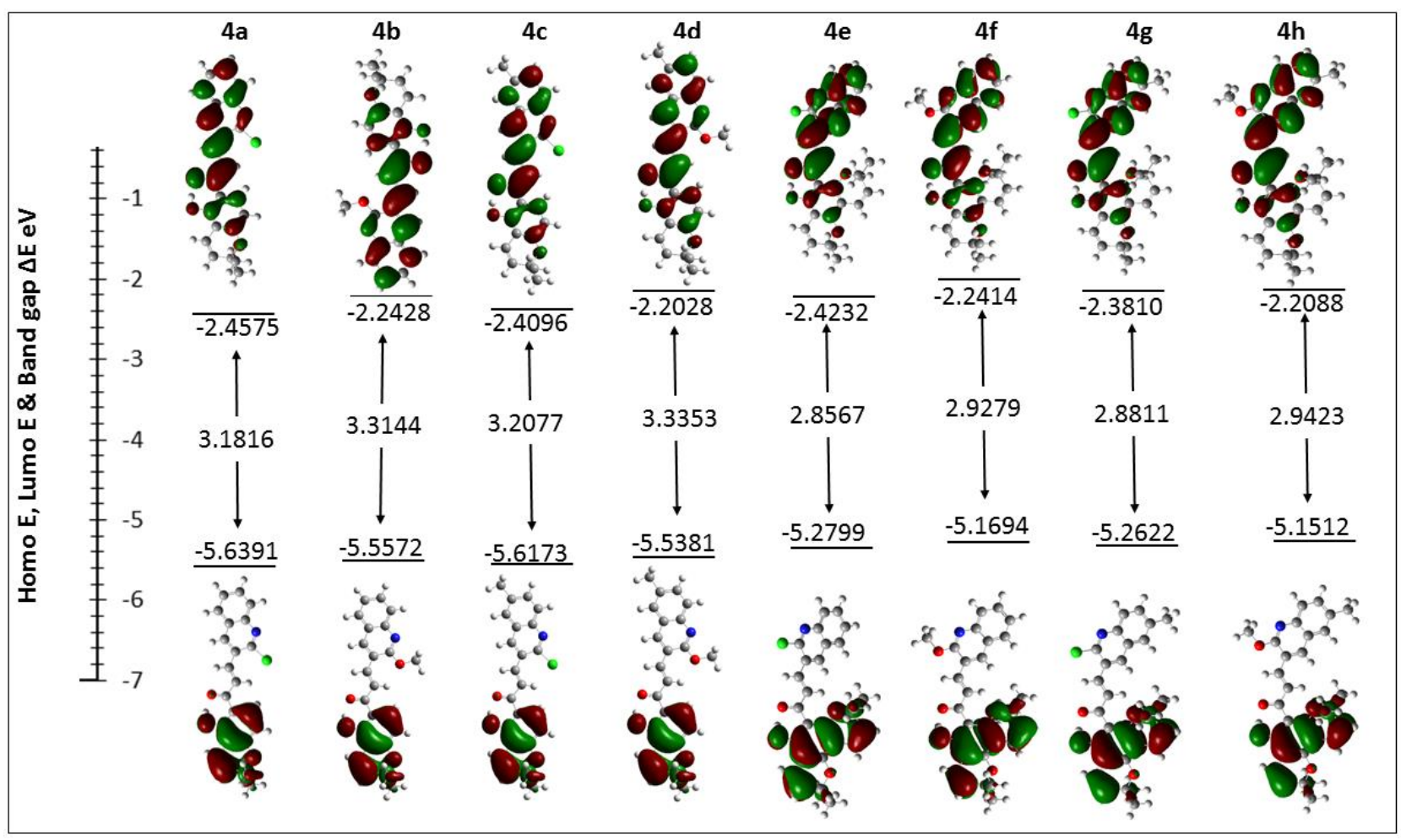

Figure 4. Frontier molecular orbitals and energies for $\mathbf{4 b}$ and $\mathbf{4 f}$ in chloroform. 

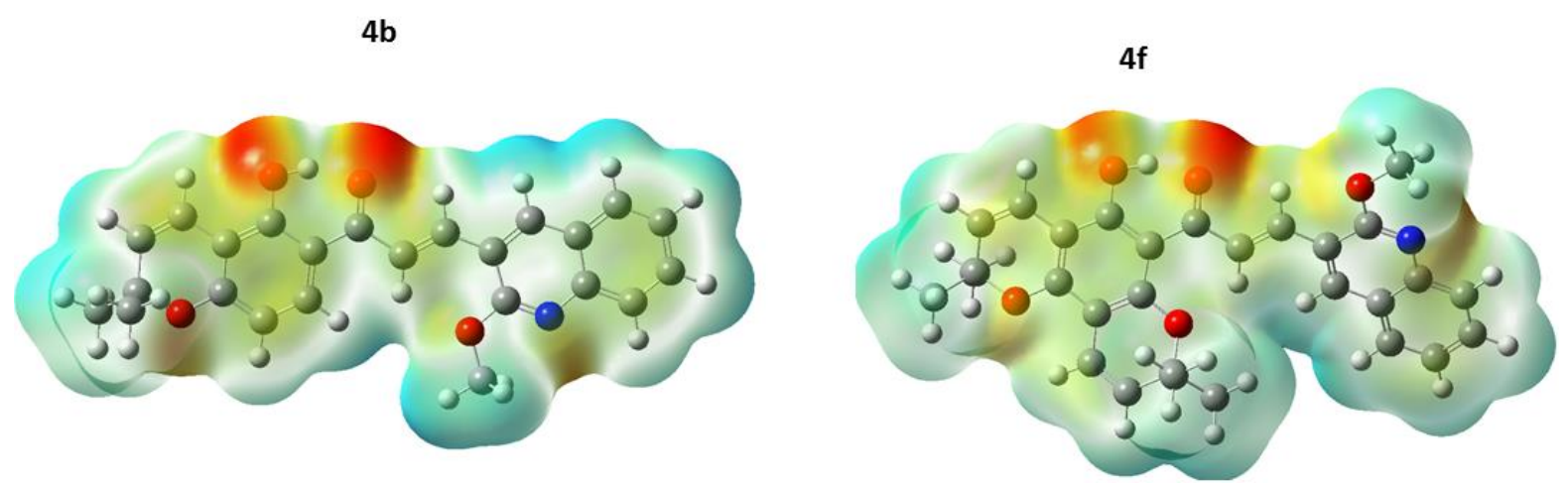

Figure 5. MEP plots for compound $\mathbf{4 b}$ and $\mathbf{4 f}$ in chloroform.

To understand the intramolecular proton transfer of $\mathbf{4 b}$ and $\mathbf{4 f}$, the relaxed potential energy scans of the optimised molecules were carried out (Figure 6) using B3LYP/6-311 ++G (d, p) level theory in the gas phase. This involved varying the redundant internal coordinates of the $\mathrm{O}-\mathrm{H}$ bond from $0.9-1.7 \AA$, with increment steps of $0.05 \AA$. The method was set to optimize the structures at each increment step and perform single point calculations. The energies were obtained for each bond length of $\mathrm{O}-\mathrm{H}$ fixed at 0.9-1.7 $\AA$ with increment steps of $0.05 \AA$. The curve compares the two molecules. Both have the same global minimum, the enol form, which is the most stable form for both molecules. A slight bend in the curves is observed, which seems to correspond to local minima. The two molecules show different relative energies at this point 5.076 and $3.989 \mathrm{Kcal} / \mathrm{mol}$ for $\mathbf{4 b}$ and $\mathbf{4 f}$ respectively. These points estimate the energy barrier required to make proton transfer possible. This means it is easier for $\mathbf{4} \mathbf{f}$ to undergo proton transfer and form the ketone than $\mathbf{4 b}$, indicating greater hydrogen bonding in $\mathbf{4 f}$, corroborating the discussion made earlier.

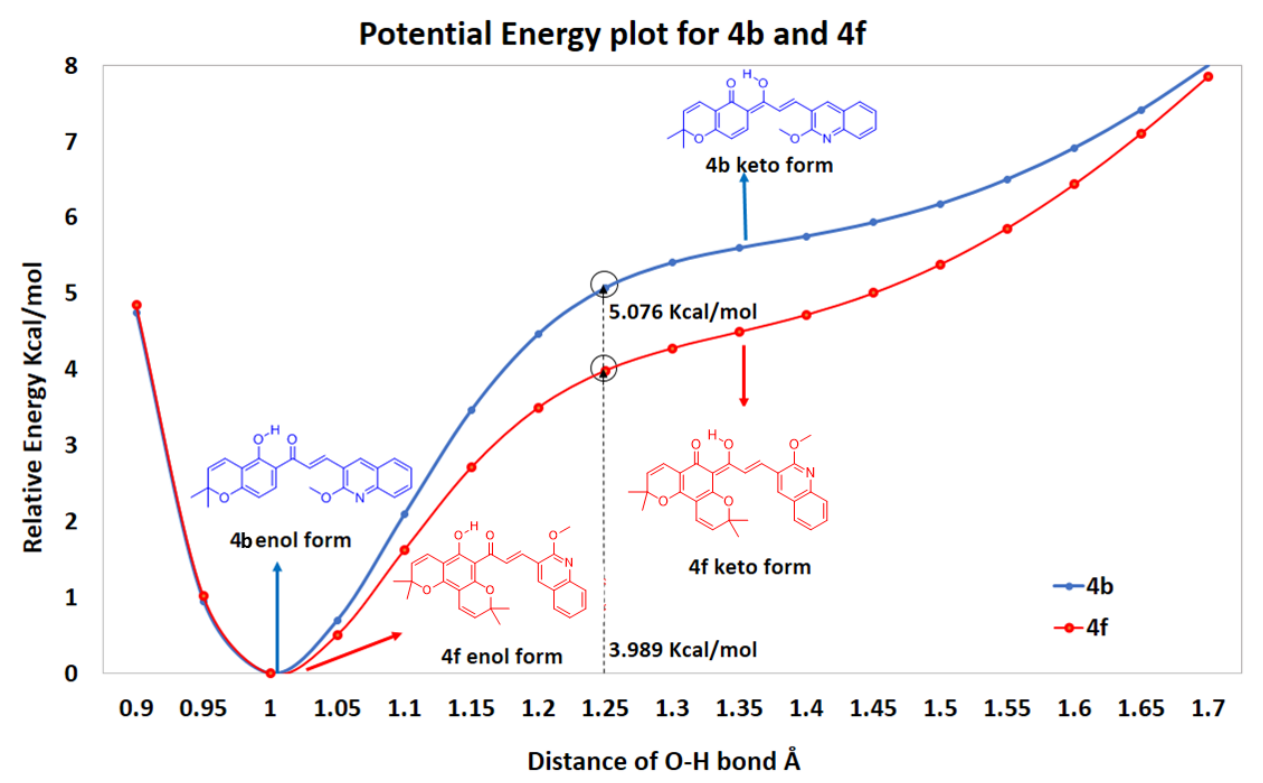

Figure 6. Potential energy plot for $\mathbf{4 b}$ and $\mathbf{4} \mathbf{f}$ in chloroform.

UV-VIS spectra of all compounds indicate two absorption maxima at 263-280 nm and 359-373 nm, corresponding to $\pi-\pi^{*}$ and $n-\pi^{*}$ transitions respectively (Figure 7). ${ }^{37}$ Compounds 4a-d have a stronger absorption intensity at $\sim 359-373 \mathrm{~nm}\left(\mathrm{n}-\pi^{*}\right)$, while 4e-h have a stronger absorption intensity at $\sim 263-280 \mathrm{~nm}$ 
$\left(\pi-\pi^{*}\right)$. This is due to extra conjugation brought about by the extra chromene ring in the dichromene derivatives.

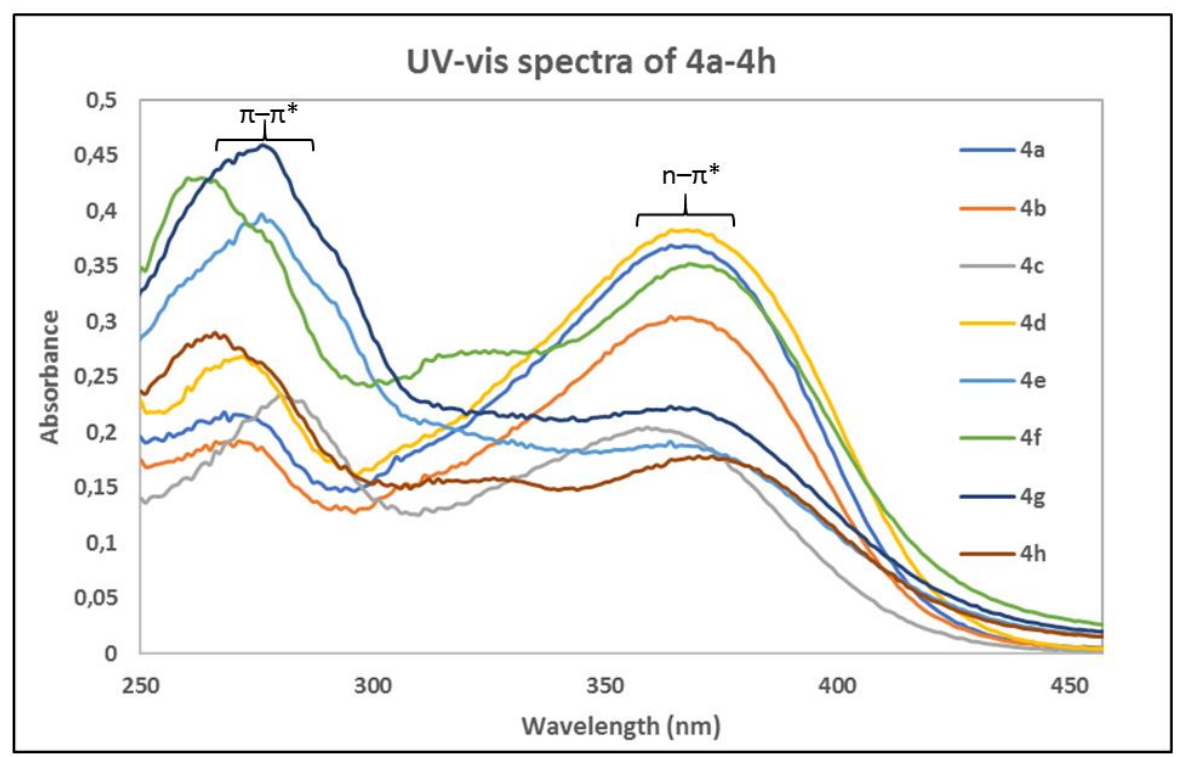

Figure 7. Overlaid UV-VIS spectra for 4a-h.

\section{Conclusions}

The hydroxy quinoline-chromene chalcones were successfully synthesised and analysed using spectral techniques. The presence of hydrogen bonding was initially confirmed by the $\mathrm{OH}$ chemical shift of the compounds. The structural difference of the chromene and dichromene derivatives resulted in observed differences in the ${ }^{1} \mathrm{H}$ NMR chemical shift of the $\mathrm{OH}$ proton. Intramolecular hydrogen bonding was shown to respond to varying temperature. The $\mathrm{O}-\mathrm{H}$ proton of both derivatives were observed to shift upfield upon temperature increase, with slightly different slopes. The potential energy scans further confirm that these molecules are stable in the enol form. The HOMO-LUMO band gaps suggest that the dichromene derivatives are less stable. The structural difference of the two derivatives result in an observable effect of the electronic and physical parameters of the molecule.

\section{Experimental Section}

General. Chemicals were purchased from Sigma-Aldrich, South Africa. Thin layer chromatography and column chromatography were performed using Kieselgel $60 \mathrm{~F}_{254}$ plates and silica gel (60-120 mesh) respectively with hexane, dichloromethane, ethyl acetate and methanol in various ratios as the mobile phase. All solvents were dried and redistilled according to standard procedures. Melting points were determined on an Electrothermal IA9100 melting point apparatus. Infrared data was recorded on a Perkin Elmer Spectrum 100 FT-IR spectrometer with universal attenuated total reflectance sampling accessory. Ultraviolet spectra were obtained on a Shimadzu UV-VIS spectrophotometer in ethanol. High-resolution mass data was obtained using a Waters Micromax LCT Premier TOF-MS instrument, operating at ambient temperatures, with a sample 
concentration of approximately $1 \mathrm{ppm} .{ }^{1} \mathrm{H}$ and ${ }^{13} \mathrm{C}$ NMR spectra were recorded at $298 \mathrm{~K}$ with 5 to $10 \mathrm{mg}$ samples dissolved in $0.5 \mathrm{~mL}$ of $\mathrm{CDCl}_{3}$ in 5-mm NMR tubes using a Bruker Avance 400-MHz NMR spectrometer (9.4 T; Bruker, Germany) (400.22 MHz for ${ }^{1} \mathrm{H}, 100.63 \mathrm{MHz}$ for ${ }^{13} \mathrm{C}$ and $376.58 \mathrm{~Hz}$ for ${ }^{19} \mathrm{~F}$ ). The FID resolution was $0.501 \mathrm{~Hz} /$ pt for ${ }^{1} \mathrm{H}$ and $0.734 \mathrm{~Hz} /$ pt for ${ }^{13} \mathrm{C}$ spectra. Chemical shifts are reported in ppm and coupling constants $(J)$ in $\mathrm{Hz} .{ }^{1} \mathrm{H}$ and ${ }^{13} \mathrm{C}$ NMR spectra were referenced to the solvent line of 7.24 and 77.0, respectively for deuterated chloroform.

\section{Synthesis}

Acetanilides Acetanilides were prepared according to the procedure of Dulla et al. ${ }^{38}$ Aniline or $p$-toluidine (15 $\mathrm{mmol}$ ) was added to a round bottomed flask containing acetic anhydride $(21 \mathrm{mmol})$ and the reaction stirred at room temperature for $30 \mathrm{~min}$. Upon completion, the contents were poured in ice water, where white or creamy precipitates were filtered and recrystallized in water.

2-Chloro-3-formylquinolines (1a and 1b). A modified method of Meth-Cohn et al. ${ }^{39}$ was used. Briefly, freshly dried DMF (33.5 mmol) was transferred to a dry round bottomed flask fitted with a condenser attached to a drying tube. $\mathrm{POCl}_{3}(93.8 \mathrm{mmol})$ was added dropwise to the DMF at 0-5 ${ }^{\circ} \mathrm{C}$ for $10-15 \mathrm{~min}$. After addition, the reaction was stirred for $20 \mathrm{~min}$ and the acetanilide $(13.4 \mathrm{mmol})$ added. The reaction was stirred at $80-90{ }^{\circ} \mathrm{C}$ for 12-16 h. On completion, the reaction mixture was cooled to room temperature and poured in ice water. A golden yellow precipitate was filtered and recrystallized in ethyl acetate.

2-Methoxy-3-formylquinolines (1c and 1d). A modified method of Waghray et al. ${ }^{40}$ was used. Briefly, the 2chloro-3-formylquinolines $\mathbf{1 a}(10.4 \mathrm{mmol})$ and $\mathbf{1 b}(10.4 \mathrm{mmol})$ were added to a solution of potassium hydroxide $(15.6 \mathrm{mmol})$ in methanol $(100 \mathrm{~mL})$ and the contents refluxed overnight. Upon completion, the reaction was cooled to room temperature and cold water added to precipitate the product, which was then filtered and dried.

1-(5-Hydroxy-2,2-dimethyl-2H-chromen-6-yl)ethanone (2). The method of Gupta et al. ${ }^{41}$ was employed with modification. 2,4-Dihydroxyacetophenone $(5.00 \mathrm{~g}, 32.90 \mathrm{mmol})$ was added to a solution of dry pyridine (3.50 $\mathrm{mL}$ ) followed by 3-methyl-but-2-enal $(3.20 \mathrm{~mL}, 32.90 \mathrm{mmol})$. The contents were refluxed for 4 hours at $110{ }^{\circ} \mathrm{C}$, after which an equivalent amount of 3-methyl-but-2-enal $(3.20 \mathrm{~mL}, 32.90 \mathrm{mmol})$ was added to the reaction mixture. The reaction was then refluxed overnight. The product was then dissolved in ethyl acetate and purified by column chromatography on silica gel using ethyl acetate and hexane (3:7).

1-(5-Hydroxy-2,2,8,8-tetramethyl-2,8-dihydropyrano[2,3-f]chromen-6-yl)ethanone (3). The method outlined in Pawar and Koorbanally ${ }^{42}$ was followed. 3-Methyl-but-2-enal $(4.70 \mathrm{~mL}, 47.6 \mathrm{mmol})$ was added to a stirred solution of 2,4,6-trihydroxyacetophenone $(2.00 \mathrm{~g}, 11.9 \mathrm{mmol})$ in dry pyridine $(1.37 \mathrm{~mL})$. The reaction was stirred at $110{ }^{\circ} \mathrm{C}$ overnight. After the reactant was completely consumed, the solvent was evaporated and the thick brown paste purified by column chromatography on silica gel using ethyl acetate and hexane (1:9).

Quinoline chromenochalcones (4a-d) and quinoline dichromenochalcones (4e-h). The method reported by Lee and $\mathrm{Kim}^{43}$ was adapted. The quinoline aldehyde 1 (1.04 mmol) and chromene 2 or dichromene 3 (0.86 $\mathrm{mmol}$ ) was added to a solution of potassium hydroxide $(8.70 \mathrm{mmol})$ in ethanol $(8.00 \mathrm{~mL})$. The reaction was stirred at room temperature for $48 \mathrm{~h}$. Upon completion, the contents were poured in cold water and 
neutralised with $\mathrm{HCl}$. The resultant precipitate was filtered and dried. The product was purified by column chromatography using $5 \%$ ethyl acetate in hexane as the mobile phase.

(E)-3-(2-Chloroquinolin-3-yl)-1-(5-hydroxy-2,2-dimethyl-2H-chromen-6-yl)prop-2-en-1-one (4a). Yellow crystalline solid; yield 40\%; $\mathrm{mp} 156-157^{\circ} \mathrm{C}$; IR (neat, $v_{\max } \mathrm{cm}^{-1}$ ) 1700 (C=O); $\lambda_{\max }(\log \varepsilon): 271$ (4.27), 367 (4.51); ${ }^{1} \mathrm{H}$ NMR $\left(400 \mathrm{MHz}, \mathrm{CDCl}_{3}\right) \delta_{\mathrm{H}} 1.46\left(6 \mathrm{H}, \mathrm{s}, \mathrm{H}-2 \mathrm{a}^{\prime} / \mathrm{H}_{-2} \mathrm{~b}^{\prime}\right), 5.59\left(1 \mathrm{H}, \mathrm{d}, J 10.1 \mathrm{~Hz}, \mathrm{H}-33^{\prime}\right), 6.39\left(1 \mathrm{H}, \mathrm{d}, J 8.8 \mathrm{~Hz}, \mathrm{H}-8^{\prime}\right)$, $6.74\left(1 \mathrm{H}, \mathrm{d}, J 10.1 \mathrm{~Hz}, \mathrm{H}-4^{\prime}\right), 7.59\left(1 \mathrm{H}, \mathrm{ddd}, J_{1} 8.6 \mathrm{~Hz}, J_{2} 7.4 \mathrm{~Hz}, J_{3} 1.0 \mathrm{~Hz}, \mathrm{H}-6\right), 7.66(1 \mathrm{H}, \mathrm{d}, J 15.5 \mathrm{~Hz}, \mathrm{H}-10)$, $7.72\left(1 \mathrm{H}, \mathrm{d}, J 8.8 \mathrm{~Hz}, \mathrm{H}-7^{\prime}\right), 7.77\left(1 \mathrm{H}, \mathrm{ddd}, J_{1} 8.4 \mathrm{~Hz}, J_{2} 7.3 \mathrm{~Hz}, J_{3} 1.0 \mathrm{~Hz}, \mathrm{H}-7\right), 7.87(1 \mathrm{H}, \mathrm{d}, J$ 8.1, H-5), $8.02(1 \mathrm{H}, \mathrm{d}$, J $8.4 \mathrm{~Hz}, \mathrm{H}-8), 8.25(1 \mathrm{H}, \mathrm{d}, J 15.5 \mathrm{~Hz}, \mathrm{H}-9), 8.47(1 \mathrm{H}, \mathrm{s}, \mathrm{H}-4), 13.47\left(1 \mathrm{H}, \mathrm{s}, \mathrm{H}-5 \mathrm{a}^{\prime}\right) ;{ }^{13} \mathrm{C} \mathrm{NMR}\left(100 \mathrm{MHz}^{\mathrm{C}} \mathrm{CDCl}\right)_{3} \delta_{\mathrm{C}}$ 28.4 (C-2a'/C-2b'), 78.1 (C-2'), 108.6 (C-8'), 109.5 (C-4a'), 113.9 (C-6'), 115.7 (C-4'), 124.8 (C-10), 127.0 (C-4a), 127.8 (C-6), 128.0 (C-5), 128.1 (C-3), 128.3 (C-3'), 128.5 (C-8), 130.8 (C-7'), 131.7 (C-7), 136.3 (C-4), 138.8 (C-9), 147.9 (C-8a), 150.4 (C-2), 160.3 (C-8'a), 161.1 (C-5'), 191.0 (C-11).

(E)-1-(5-Hydroxy-2,2-dimethyl-2H-chromen-6-yl)-3-(2-methoxyquinolin-3-yl)prop-2-en-1-one (4b). Yellow crystalline solid; yield 43\%; mp 152-153 ${ }^{\circ} \mathrm{C}$; IR (neat, $v_{\max } \mathrm{cm}^{-1}$ ) 1630 (C=O); $\lambda_{\max }(\log \varepsilon): 271$ (4.26), 364 (4.56); ${ }^{1} \mathrm{H}$ NMR $\left(400 \mathrm{MHz}, \mathrm{CDCl}_{3}\right) \delta_{\mathrm{H}} 1.46\left(6 \mathrm{H}, \mathrm{s}, \mathrm{H}-2 \mathrm{a}^{\prime} / \mathrm{H}-2 \mathrm{~b}^{\prime}\right), 4.18(3 \mathrm{H}, \mathrm{s}, \mathrm{H}-2 \mathrm{a}), 5.58\left(1 \mathrm{H}, \mathrm{d}, J 10.4 \mathrm{~Hz}, \mathrm{H}-3^{\prime}\right), 6.39(1 \mathrm{H}$, d, J $\left.8.9 \mathrm{~Hz}, \mathrm{H}-8^{\prime}\right), 6.75\left(1 \mathrm{H}, \mathrm{d}, J 10.4 \mathrm{~Hz}, \mathrm{H}-4\right.$ ') $7.38\left(1 \mathrm{H}, \mathrm{ddd}, J_{1} 8.3 \mathrm{~Hz}, J_{2} 7.7 \mathrm{~Hz}, J_{3} 1.5 \mathrm{~Hz}, \mathrm{H}-6\right), 7.63\left(1 \mathrm{H}, \mathrm{ddd}, J_{1}\right.$ $\left.8.3 \mathrm{~Hz}, J_{2} 7.4 \mathrm{~Hz}, J_{3} 1.1 \mathrm{~Hz}, \mathrm{H}-7\right), 7.73(1 \mathrm{H}, \mathrm{d}, J 8.9 \mathrm{~Hz}, \mathrm{H}-7$ '), $7.75(1 \mathrm{H}, \mathrm{d}, J 8.3 \mathrm{~Hz}, \mathrm{H}-5), 7.83(1 \mathrm{H}, \mathrm{d}, J 8.3 \mathrm{~Hz}, \mathrm{H}-8)$, $7.87(1 \mathrm{H}, \mathrm{d}, J 15.8 \mathrm{~Hz}, \mathrm{H}-10), 8.06(1 \mathrm{H}, \mathrm{d}, J 15.8 \mathrm{~Hz}, \mathrm{H}-9), 8.24(1 \mathrm{H}, \mathrm{s}, \mathrm{H}-4), 13.68\left(1 \mathrm{H}, \mathrm{s}, \mathrm{H}-5 \mathrm{a}^{\prime}\right) ;{ }^{13} \mathrm{C} \mathrm{NMR}(100$ $\mathrm{MHz}, \mathrm{CDCl}_{3}$ ) $\delta_{\mathrm{C}} 28.4$ (C-2a'/C-2b'), 53.9 (C-2a), 77.9 (C-2'), 108.4 (C-8'), 109.4 (C-4a'), 114.2 (C-6'), 115.9 (C-4'), 120.2 (C-3), 123.5 (C-10), 124.7 (C-6), 125.0 (C-4a), 127.1 (C-8) 128.0 (C-5), 128.2 (C-3'), 130.8 (C-7, C-7'), 138.7 (C-9), 139.1 (C-4), 146.9 (C-8a), 160.0 (C-2), 160.2 (C-8a'), 161.1 (C-5'), 192.1 (C-11); HRMS (neg) m/z 386.1398 [M-H] (calcd. for $\left.\mathrm{C}_{24} \mathrm{H}_{20} \mathrm{NO}_{4}: 386.1392\right)$.

(E)-3-(2-Chloro-6-methylquinolin-3-yl)-1-(5-hydroxy-2,2-dimethyl-2H-chromen-6-yl)prop-2-en-1-one (4c). Yellow crystalline solid; yield 38\%; mp 189-191 ${ }^{\circ} \mathrm{C}$; IR (neat, $v_{\max }, \mathrm{cm}^{-1}$ ) 1631 (C=O); $\lambda_{\max }(\log \varepsilon): 280$ (4.36), 359 (4.30); ${ }^{1} \mathrm{H}$ NMR (400 MHz, CDCl $\left.{ }_{3}\right) \delta_{\mathrm{H}} 1.46\left(6 \mathrm{H}, \mathrm{s}, \mathrm{H}-2 \mathrm{a}^{\prime} / \mathrm{H}-2 \mathrm{~b}^{\prime}\right), 2.53(3 \mathrm{H}, \mathrm{s}, \mathrm{H}-6 \mathrm{a}), 5.59\left(1 \mathrm{H}, \mathrm{d}, J 10.0 \mathrm{~Hz}, \mathrm{H}-3^{\prime}\right)$, $6.39\left(1 \mathrm{H}, \mathrm{d}, J 8.9 \mathrm{~Hz}, \mathrm{H}-8^{\prime}\right), 6.74\left(1 \mathrm{H}, \mathrm{d}, J 10.0 \mathrm{~Hz}, \mathrm{H}-4{ }^{\prime}\right), 7.58\left(1 \mathrm{H}, \mathrm{dd}, J_{1} 8.6 \mathrm{~Hz}, J_{2} 1.8 \mathrm{~Hz}, \mathrm{H}-7\right), 7.62(1 \mathrm{H}, \mathrm{s}, \mathrm{H}-5)$, $7.63(1 \mathrm{H}, \mathrm{d}, J 15.4 \mathrm{~Hz}, \mathrm{H}-10), 7.71(1 \mathrm{H}, \mathrm{d}, J 8.9 \mathrm{~Hz}, \mathrm{H}-7$ ') $7.89(1 \mathrm{H}, \mathrm{d}, J 8.6 \mathrm{~Hz}, \mathrm{H}-8), 8.23(1 \mathrm{H}, \mathrm{d}, J 15.4 \mathrm{~Hz}, \mathrm{H}-9)$, $8.36(1 \mathrm{H}, \mathrm{s}, \mathrm{H}-4), 13.48\left(1 \mathrm{H}, \mathrm{s}, \mathrm{H}-5 \mathrm{a}^{\prime}\right) ;{ }^{13} \mathrm{C} \mathrm{NMR}\left(100 \mathrm{MHz}, \mathrm{CDCl}_{3}\right) \delta_{\mathrm{C}} 21.6$ (C-6a), 28.4 (C-2a'/C-2b'), 78.1 (C-2'), 108.6 (C-8'), 109.5 (C-4a'), 113.9 (C-6'), 115.8 (C-4'), 124.5 (C-10), 126.8 (C-5), 127.0 (C-4a), 127.8 (C-3), 128.1 (C-8), 128.3 (C-3'), 130.8 (C-7'), 134.0 (C-7), 135.7 (C-4), 137.9 (C-6), 139.0 (C-9), 146.6 (C-8a), 160.3 (C-8a'), 161.1(C-5'), 191.0 (C-11); HRMS (neg) $\mathrm{m} / z 404.1049$ [M-H] (calcd. for $\mathrm{C}_{24} \mathrm{H}_{19} \mathrm{NO}_{3} \mathrm{Cl} 404.1053$ ).

(E)-1-(5-Hydroxy-2,2-dimethyl-2H-chromen-6-yl)-3-(2-methoxy-6-methylquinolin-3-yl)prop-2-en-1-one (4d).

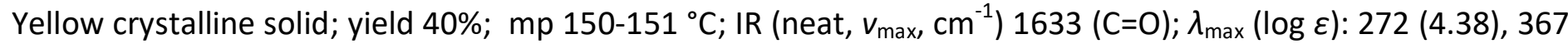
(4.53); ${ }^{1} \mathrm{H}$ NMR (400 MHz, CDCl $) \delta_{\mathrm{H}} 1.46\left(6 \mathrm{H}, \mathrm{s}, \mathrm{H} 2 \mathrm{a}^{\prime} / \mathrm{H}-2 \mathrm{~b}^{\prime}\right), 2.47$ (3H, s, H-6a), 4.15 (3H, s, H-2a), 5.58 (1H, d, J $\left.10.2 \mathrm{~Hz}, \mathrm{H}-3^{\prime}\right), 6.38\left(1 \mathrm{H}, \mathrm{d}, J 9.0 \mathrm{~Hz}, \mathrm{H}-8^{\prime}\right), 6.74\left(1 \mathrm{H}, \mathrm{d}, J 10.2 \mathrm{~Hz}, \mathrm{H}-4^{\prime}\right), 7.46\left(1 \mathrm{H}, \mathrm{dd}, J_{1} 8.5 \mathrm{~Hz}, J_{2} 1.9 \mathrm{~Hz}, \mathrm{H}-7\right)$, $7.49(1 \mathrm{H}, \mathrm{s}, \mathrm{H}-5), 7.71(2 \mathrm{H}, \mathrm{d}, J 9.0 \mathrm{~Hz}, \mathrm{H}-7$ ' , H-8), $7.85(1 \mathrm{H}, \mathrm{d}, J 15.6 \mathrm{~Hz}, \mathrm{H}-10), 8.02(1 \mathrm{H}, \mathrm{d}, J 15.6 \mathrm{~Hz}, \mathrm{H}-9), 8.13$ $(1 \mathrm{H}, \mathrm{s}, \mathrm{H}-4), 13.70\left(1 \mathrm{H}, \mathrm{s}, \mathrm{H}-5 \mathrm{a}^{\prime}\right) ;{ }^{13} \mathrm{C}$ NMR (100 MHz, CDCl ${ }_{3} \delta_{\mathrm{C}} 21.3$ (C-6a), 28.4 (C-2a'/C-2b'), 53.8 (C-2a), 77.9 (C-2'), 108.3 (C-8'), 109.4 (C-4a'), 114.2 (C-6'), 115.9 (C-4'), 120.0 (C-3), 123.3 (C-10), 125.0 (C-4a), 126.8 (C-8), 127.0 (C-5), 128.1 (C-3'), 130.8 (C-7'), 132.9 (C-7), 134.3 (C-6), 138.7 (C-4), 138.9 (C-9), 145.2 (C-8a), 159.8 (C8a'), 159.9 (C-2), 161.0 (C-5'), 192.2 (C-11); HRMS (neg) m/z 400.1541 [M-H] (calcd. for $\mathrm{C}_{25} \mathrm{H}_{22} \mathrm{NO}_{4} 400.1549$ ).

(E)-3-(2-Chloroquinolin-3-yl)-1-(5-hydroxy-2,2,8,8-tetramethyl-2H,8H-pyrano[2,3-f]chromen-6-yl)prop-2-en1-one (4e). Brown crystalline solid; Yield 45\%; mp 215-217 ${ }^{\circ} \mathrm{C}$; IR (neat) $v_{\max } 1639 \mathrm{~cm}^{-1}$ (C=O); $\lambda_{\max }(\log \varepsilon): 276$ (4.66), 364 (4.34); ${ }^{1} \mathrm{H}$ NMR (400 MHz, CDCl ${ }_{3}$ ) $\delta_{\mathrm{H}} 1.45$ (6H, s, H-2a'/H-2b'), 1.53 (6H, s, H-9a'/H-9b'), 5.47 (1H, d, J $\left.10.0 \mathrm{~Hz}, \mathrm{H}-10^{\prime}\right), 5.48\left(1 \mathrm{H}, \mathrm{d}, J 10.0 \mathrm{~Hz}, \mathrm{H}-3^{\prime}\right), 6.61\left(1 \mathrm{H}, \mathrm{d}, J 10.0 \mathrm{~Hz}, \mathrm{H}-11^{\prime}\right), 6.68\left(1 \mathrm{H}, \mathrm{d}, J 10.0 \mathrm{~Hz}, \mathrm{H}-4^{\prime}\right), 7.58$ 
$\left(1 \mathrm{H}, \mathrm{ddd}, J_{1} 8.1 \mathrm{~Hz}, J_{2} 7.7 \mathrm{~Hz}, J_{3} 0.9 \mathrm{~Hz}, \mathrm{H}-6\right), 7.75\left(1 \mathrm{H}\right.$, ddd, J1 $\left.8.4 \mathrm{~Hz}, J_{2} 7.7 \mathrm{~Hz}, J_{3} 1.5 \mathrm{~Hz}, \mathrm{H}-7\right), 7.81(1 \mathrm{H}, \mathrm{d}, J 8.1$ $\mathrm{Hz}, \mathrm{H}-5), 8.02(1 \mathrm{H}, \mathrm{d}, J 8.4 \mathrm{~Hz}, \mathrm{H}-8), 8.13(1 \mathrm{H}, \mathrm{d}, J 15.5 \mathrm{~Hz}, \mathrm{H}-9), 8.19(1 \mathrm{H}, \mathrm{d}, J$ 15.5, H-10), $8.41(1 \mathrm{H}, \mathrm{s}, \mathrm{H}-4)$, $14.14\left(1 \mathrm{H}, \mathrm{s}, \mathrm{H}-5 \mathrm{a}^{\prime}\right) ;{ }^{13} \mathrm{C}$ NMR $\left(100 \mathrm{MHz}, \mathrm{CDCl}_{3}\right) \delta_{\mathrm{C}} 28.1$ (C-2a'/C-2b'), 28.5 (C-9a'/C-9b'), 78.5 (C-2', C-9'), 102.0 (C-4a', C-8'), 105.8 (C-6'), 116.1 (C-4'), 116.6 (C-11'), 124.8 (C-10'), 125.6 (C-3'), 127.2 (C-4a), 127.6 (C-6), 127.8 (C-5), 128.5 (C-8), 128.9 (C-3), 131.4 (C-7), 131.9 (C-10), 135.7 (C-4), 136.2 (C-9), 147.7 (C-8a), 150.6 (C-2), 155.6 (C-8a'), 156.9 (C-7'), 161.6 (C-5'), 191.9 (C-11); HRMS (neg) m/z 472.1324 [M-H] (calcd. for $\mathrm{C}_{28} \mathrm{H}_{23} \mathrm{NO}_{4} \mathrm{Cl}$ 472.1316).

(E)-1-(5-Hydroxy-2,2,8,8-tetramethyl-2H,8H-pyrano[2,3-f]chromen-6-yl)-3-(2-methoxyquinolin-3-yl)prop-2en-1-one (4f). Brown crystalline solid; yield 42\%; mp 178-180 ${ }^{\circ} \mathrm{C}$; IR (neat, $v_{\max } \mathrm{cm}^{-1}$ ) 1700 (C=O); $\lambda_{\max }(\log \varepsilon)$ : 263 (4.58), 368 (4.27); ${ }^{1} \mathrm{H}$ NMR (400 MHz, CDCl ${ }_{3} \delta_{\mathrm{H}} 1.45$ (6H, s, H-2a'/H-2b'), 1.54 (6H, s, H-9a'/H-9b'), 4.16 $(3 \mathrm{H}, \mathrm{s}, \mathrm{H}-2 \mathrm{a}), 5.47\left(2 \mathrm{H}, \mathrm{d}, J 10.0 \mathrm{~Hz}, \mathrm{H}-3^{\prime}, \mathrm{H}-10^{\prime}\right), 6.61\left(1 \mathrm{H}, \mathrm{d}, J 10.0 \mathrm{~Hz}, \mathrm{H}-11^{\prime}\right), 6.69$ (1H, d, J $\left.10.0 \mathrm{~Hz}, \mathrm{H}-4^{\prime}\right), 7.38$ $\left(1 \mathrm{H}, \mathrm{ddd}, J_{1} 8.0 \mathrm{~Hz}, J_{2} 7.5 \mathrm{~Hz}, J_{3} 1.2 \mathrm{~Hz}, \mathrm{H}-6\right), 7.63\left(1 \mathrm{H}, \mathrm{ddd}, J_{1} 8.5 \mathrm{~Hz}, J_{2} 7.5 \mathrm{~Hz}, J_{3} 1.2 \mathrm{~Hz}, \mathrm{H}-7\right), 7.71(1 \mathrm{H}, \mathrm{d}, J 8.0$ Hz, H-5), $7.83(1 \mathrm{H}, \mathrm{d}, J 8.5 \mathrm{~Hz}, \mathrm{H}-8), 7.97(1 \mathrm{H}, \mathrm{d}, J 15.8 \mathrm{~Hz}, \mathrm{H}-9), 8.21(1 \mathrm{H}, \mathrm{s}, \mathrm{H}-4), 8.27(1 \mathrm{H}, \mathrm{d}, J$ 15.8, H-10), $14.30\left(1 \mathrm{H}, \mathrm{s}, \mathrm{H}-5 \mathrm{a}^{\prime}\right) ;{ }^{13} \mathrm{C}$ NMR (100 MHz, CDCl ${ }_{3}$ ) $\delta_{\mathrm{C}} 27.9$ (C-9a'/C-9b'), 28.4 (C-2a'/C-2b'), 53.9 (C-2a), 78.3 (C-9'), 78.4 (C-2'), 102.6 (C-4a', C-8'), 106.1 (C-6'), 116.3 (C-4'), 116.6 (C-11'), 121.0 (C-3), 124.6 (C-6), 124.9 (C-10'), 125.2 (C-4a), 125.4 (C-3'), 127.0 (C-8), 127.9 (C-5), 130.5 (C-7), 130.7 (C-10), 136.2 (C-9), 138.1 (C-4), 146.7 (C8a), 155.4 (C-8a'), 156.2 (C-7'), 160.3 (C-2), 161.4 (C-5'), 193.1 (C-11); HRMS (neg) m/z 468.1821 [M-H] (calcd. for $\left.\mathrm{C}_{30} \mathrm{H}_{22} \mathrm{NO}_{5} 468.1824\right)$.

(E)-3-(2-Chloro-6-methylquinolin-3-yl)-1-(5-hydroxy-2,2,8,8-tetramethyl-2H,8H-pyrano[2,3-f]chromen-6-

yl)prop-2-en-1-one (4g). Brown crystalline solid; Yield 46\%; mp 189-190 ${ }^{\circ} \mathrm{C}$; IR (neat, $\left.v_{\max } \mathrm{cm}^{-1}\right) 1700(\mathrm{C}=\mathrm{O})$; $\lambda_{\max }(\log \varepsilon): 276$ (4.60), 369 (4.51); ${ }^{1} \mathrm{H}$ NMR (400 MHz, CDCl $) \delta_{\mathrm{H}} 1.45\left(6 \mathrm{H}, \mathrm{s}, \mathrm{H}-2 \mathrm{a}^{\prime} / \mathrm{H}-2 \mathrm{~b}^{\prime}\right), 1.53\left(6 \mathrm{H}, \mathrm{s}, \mathrm{H}-9 \mathrm{a}^{\prime} / \mathrm{H}-\right.$ 9b'), $2.53(3 \mathrm{H}, \mathrm{s}, \mathrm{H}-6 \mathrm{a}), 5.48\left(1 \mathrm{H}, \mathrm{d}, J 10.0 \mathrm{~Hz}, \mathrm{H}-3^{\prime}\right), 5.49\left(1 \mathrm{H}, \mathrm{d}, J 10.0 \mathrm{~Hz}, \mathrm{H}-10^{\prime}\right), 6.61\left(1 \mathrm{H}, \mathrm{d}, J 10.0 \mathrm{~Hz}, \mathrm{H}-11^{\prime}\right)$, $6.68\left(1 \mathrm{H}, \mathrm{d}, J 10.0 \mathrm{~Hz}, \mathrm{H}-4{ }^{\prime}\right), 7.54(1 \mathrm{H}, \mathrm{s}, \mathrm{H}-5), 7.57\left(1 \mathrm{H}, \mathrm{dd}, J_{1} 8.4, J_{2} 1.8 \mathrm{~Hz}, \mathrm{H}-7\right), 7.90(1 \mathrm{H}, \mathrm{d}, J 8.4 \mathrm{~Hz}, \mathrm{H}-8), 8.11$ $(1 \mathrm{H}, \mathrm{d}, J 15.7 \mathrm{~Hz}, \mathrm{H}-9), 8.16(1 \mathrm{H}, \mathrm{d}, J 15.7 \mathrm{~Hz}, \mathrm{H}-10), 8.31(1 \mathrm{H}, \mathrm{s}, \mathrm{H}-4), 14.16\left(1 \mathrm{H}, \mathrm{s}, \mathrm{H}-5 \mathrm{a}^{\prime}\right) ;{ }^{13} \mathrm{C} \mathrm{NMR}(100 \mathrm{MHz}$, $\mathrm{CDCl}_{3}$ ) $\delta_{\mathrm{C}} 21.6$ (C-6a), 28.2 (C-9a'/C-9b'), 28.5 (C-2a'/C-2b'), 78.5 (C-2', C-9'), 102.6 (C-8'), 102.7 (C-4a'), 105.9 (C-6'), 116.1 (C-4'), 116.6 (C-11'), 124.8 (C-10'), 125.5 (C-3'), 126.6 (C-5), 127.2 (C-4a), 128.2 (C-8), 128.7 (C-3), 131.6 (C-10), 133.7 (C-7), 135.1 (C-4), 136.4 (C-9), 137.7 (C-6), 146.4 (C-8a), 149.7 (C-2), 155.7 (C-8a'), 156.2 (C$\left.7^{\prime}\right), 161.5$ (C-5'), 191.9 (C-11); HRMS (neg) $\mathrm{m} / \mathrm{z} 482.1975$ [M-H] (calcd. for $\mathrm{C}_{30} \mathrm{H}_{28} \mathrm{NO}_{5} 482.1967$ ).

(E)-1-(5-Hydroxy-2,2,8,8-tetramethyl-2H,8H-pyrano[2,3-f]chromen-6-yl)-3-(2-methoxy-6-methylquinolin-3yl)prop-2-en-1-one (4h). Brown crystalline solid; yield 43\%; mp 148-149 ${ }^{\circ} \mathrm{C}$; IR (neat, $\left.v_{\max } \mathrm{cm}^{-1}\right) 1700(\mathrm{C}=\mathrm{O})$; $\lambda_{\max }(\log \varepsilon): 266$ (4.66), 373 (4.34); ${ }^{1} \mathrm{H}$ NMR (400 MHz, CDCl $) \delta_{\mathrm{H}} 1.44\left(6 \mathrm{H}, \mathrm{s}, \mathrm{H}-2 \mathrm{a}^{\prime} / \mathrm{H}-2 \mathrm{~b}^{\prime}\right), 1.54\left(6 \mathrm{H}, \mathrm{s}, \mathrm{H} 9 \mathrm{a}^{\prime} / \mathrm{H}-\right.$ 9b'), $2.48(3 \mathrm{H}, \mathrm{s}, \mathrm{H}-6 \mathrm{a}), 4.13(3 \mathrm{H}, \mathrm{s}, \mathrm{H}-2 \mathrm{a}), 5.47\left(2 \mathrm{H}, \mathrm{d}, J 10.0 \mathrm{~Hz}, \mathrm{H}-3^{\prime}, \mathrm{H}-10^{\prime}\right), 6.61\left(1 \mathrm{H}, \mathrm{d}, J 10.0 \mathrm{~Hz}, \mathrm{H}-11^{\prime}\right), 6.68$ $\left(1 \mathrm{H}, \mathrm{d}, J 10.0 \mathrm{~Hz}, \mathrm{H}-4{ }^{\prime}\right), 7.46\left(1 \mathrm{H}, \mathrm{dd}, J_{1} 8.6, J_{2} 1.6 \mathrm{~Hz}, \mathrm{H}-7\right), 7.47(1 \mathrm{H}, \mathrm{s}, \mathrm{H}-5), 7.72(1 \mathrm{H}, \mathrm{d}, J 8.6 \mathrm{~Hz}, \mathrm{H}-8), 7.97(1 \mathrm{H}$, d, J $16.0 \mathrm{~Hz}, \mathrm{H}-9), 8.12(1 \mathrm{H}, \mathrm{s}, \mathrm{H}-4), 8.23(1 \mathrm{H}, \mathrm{d}, J 16.0 \mathrm{~Hz}, \mathrm{H}-10), 14.31\left(1 \mathrm{H}, \mathrm{s}, \mathrm{H}-5 \mathrm{a}^{\prime}\right) ;{ }^{13} \mathrm{C} \mathrm{NMR}\left(100 \mathrm{MHz} \mathrm{CDCl}_{3}\right)$ $\delta_{C} 21.3$ (C-6a), 28.0 (C-9a'/C-9b'), 28.4 (C-2a'/C-2b'), 53.8 (C-2a), 78.3 (C-2'/C-9'), 102.5 (C-4a'), 102.6 (C-8'), 106.1 (C-6'), 116.3 (C-4'), 116.6 (C-11'), 120.8 (C-3), 124.9 (C-10'), 125.1 (C-4a), 125.4 (C-3'), 126.7 (C-8), 126.9 (C-5), 130.5 (C-10), 132.7 (C-7), 134.2 (C-6), 136.6 (C-9), 137.7 (C-4), 145.1 (C-8a), 155.4 (C-8a'), 156.2 (C-7'), 159.9 (C-2), 161.4 (C-5'), 193.2 (C-11); HRMS (neg) m/z 482.1961 [M-H] (calcd. for $\mathrm{C}_{30} \mathrm{H}_{28} \mathrm{NO}_{5}$ 482.1967).

\section{Computational studies}

The 2D structure of the synthesized molecular hybrids 6a-6I were prepared using ChemBioDraw Ultra 13.0 and optimized using DFT with B3LYP at 6-31G $(d, p)$ level basis sets. ${ }^{44-46}$ For intramolecular hydrogen bonding calculations, compounds $\mathbf{4 b}$ and $\mathbf{4 f}$ were further optimized using 6-311G (d, p). ${ }^{47}$ The harmonic vibrational frequency calculations of the optimised molecules were evaluated at the same level of theory as optimisation 
and the absence of imaginary frequencies confirmed that the stationary points obtained correspond to the true minima of the potential energy surface. Symmetry of the molecules was not specified in all calculations. Software default convergence parameters were used and the optimisations carried out in the gaseous phase. Calculations were carried out using Gaussian 09 A.02 and visualized using Gauss View 5.0.8 software. ${ }^{48-49}$ The $^{\text {. }}$ final optimised 3D structures were used to obtain frontier molecular orbitals, HOMO-LUMO energies and molecular electrostatic potential (MEP) plots. Potential energy scans were determined for $\mathbf{4 b}$ and $\mathbf{4 f}$ to investigate the potential energy barrier of the intramolecular proton transfer of the $\mathrm{OH}$ proton and its effect on molecular structure.

\section{Single crystal $X$-ray diffraction analysis}

The compounds were dissolved in methanol and allowed to slowly crystallise at room temperature. Crystal structures of $\mathbf{4 b}$ and $\mathbf{4 f}$ were determined on a Bruker Smart APEX II diffractometer with Mo Ka radiation. Data reduction was carried out using the System Administrator's Integrated Network Tool (SAINT+). SHELXS was used to solve and refine the structure. Hydrogen atoms were positioned geometrically and refined isotropically. Crystallographic images were prepared using Mercury 3.9. Crystallographic data has been deposited with the Cambridge Crystallographic Data Centre, CCDC, 12 Union Road, Cambridge CB21EZ, UK. Copies of the data can be obtained free of charge on quoting the depository numbers CCDC-1895603 and 1895604 (Fax: +44-1223-336-033; E-Mail: deposit@ccdc.cam.ac.uk http://www.ccdc.cam.ac.uk ).

\section{Acknowledgements}

NK thanks the National Research Foundation South Africa for a Competitive Grant for Rated Researchers (Grant No. 118534) and Incentive Funding for Rated Researchers (Grant No. 114817), and the CSIR Armscor Ledger Grant for research costs and a bursary for Lamla Thungatha.

\section{Supplementary Material}

${ }^{1} \mathrm{H}$ and ${ }^{13} \mathrm{C}$ NMR data, High Resolution Mass spectra and graphs depicting the changes in the ${ }^{1} \mathrm{H}$ NMR chemical shifts of certain resonances as a function of temperature can be found in the supplementary material file.

\section{References}

1. Kaur, K.; Jain, M.; Reddy, R.P.; Jain, R. Eur. J. Med. Chem. 2010, 45, 3245.

https://doi.org/10.1016/j.ejmech.2010.04.011

2. Marella, A.; Tanwar, O.P.; Saha, R.; Ali, M.R.; Srivastava, S.; Akhter, M.; Shaquiquzzaman, M.; Alam, M.M. Saudi Pharm. J. 2013, 21, 1.

https://doi.org/10.1016/j.jsps.2012.03.002

3. Garudachari, B.; Isloor, A. M.; Satyanarayana, M.N.; Fun, H.-K.; Hegde, G. Eur. J. Med. Chem. 2014, 74, 324. https://doi.org/10.1016/i.ejmech.2014.01.008

4. Duval, A.R.; Carvalho, P.H.; Soares, M.C.; Gouvêa, D.P.; Siqueira, G.M.; Lund, R.G.; Cunico, W.

ScientificWorldJournal 2011, 11, 1489. 
https://doi.org/10.1100/tsw.2011.141

5. Afzal, O.; Kumar, S.; Haider, M.R.; Ali, M.R.; Kumar, R.; Jaggi, M.; Bawa, S. Eur. J. Med. Chem. 2015, $97,871$. https://doi.org/10.1016/i.ejmech.2014.07.044

6. Candéa, A.L.P.; Ferreira, M.D.L.; Pais, K.C.; Cardoso, L.N.D.F.; Kaiser, C.R.; Henriques, M.D.G.M.D.O.; Lourenço, M.C.S.; Bezerra, F.A.F.M.; Souza, M.V.N.D. Bioorg. Med. Chem. Lett. 2009, 19, 6272. https://doi.org/10.1016/i.bmcl.2009.09.098

7. Gopinath, V.S.; Rao, M.; Shivahare, R.; Vishwakarma, P.; Ghose, S.; Pradhan, A.; Hindupur, R.; Sarma, K.D.; Gupta, S.; Puri, S.K.; Launay, D.; Martin, D. Bioorg. Med. Chem. Lett. 2014, 24, 2046. https://doi.org/10.1016/j.bmcl.2014.03.065

8. El-Feky, S.A.H.; El-Samii, Z.K.A.; Osman, N.A.; Lashine, J.; Kamel, M.A.; Thabet, H.K. Bioorg. Chem. 2015, 58, 104.

https://doi.org/10.1016/j.bioorg.2014.12.003

9. Garrison, A.T.; Abouelhassan, Y.; Yang, H.; Yousaf, H.H.; Nguyen, T.J.; Huigens III, R.W. MedChemComm, 2017, 8, 720.

https://doi.org/10.1039/C6MD00381H

10. Ramírez-Prada, J.; Robledo, S.M.; Vélez, I.D.; Crespo, M.D.P.; Quiroga, J.; Abonia, R.; Montoya, A.; Svetaz, L.; Zacchino, S.; Insuasty, B. Eur. J. Med. Chem. 2017, 131, 237. https://doi.org/10.1016/i.ejmech.2017.03.016

11. Nikam, M.D.; Mahajan, P.S.; Damale, M.G.; Sangshetti, J.N.; Dabhade, S.K.; Shinde, D.W.; Gill, C.H. Med. Chem. Res. 2015, 24, 3372.

https://doi.org/10.1007/s00044-015-1385-x

12. Wang, L.; Chen, G.; Lu, X.; Wang, S.; Han, S.; Li, Y.; Ping, G.; Jiang, X.; Li, H.; Yang, J.; Wu, C. Eur. J. Med. Chem. 2015, 89, 88.

https://doi.org/10.1016/i.ejmech.2014.10.036

13. Wei, Z.; Yang, Y.; Xie, C.; Li, C.; Wang, G.; Ma, L.; Xiang, M.; Sun, J.; Wei, Y.; Chen, L. Fitoterapia 2014, 97, 172.

https://doi.org/10.1016/j.fitote.2014.06.002

14. Dinesh, K.; Pooja, S.; Harmanpreet, S.; Kuna, N.; Girish Kumar, G.; Subheet Kumar, J.; Fidele, N.K. RSC Advances 2017, 7, 36977.

https://doi.org/10.1039/C7RA05441F

15. Filarowski, A.; Koll, A.; Kochel, A.; Kalenik, J.; Hansen, P.E. J. Mol. Struct. 2004, 700, 67. https://doi.org/10.1016/j.molstruc.2004.01.033

16. Weller, A. Z. Electrochem., Ber Bunsenges Phys Chem. 1956, 60, 1144.

17. Sobczyk, L.; Chudoba, D.; Tolstoy, P.M.; Filarowski, A. Molecules 2016, 21, 1657. https://doi.org/10.3390/molecules21121657

18. Kanaani, A.; Ajloo, D.; Ghasemian, H.; Kiyani, H.; Vakili, M.; Mosallanezhad, A. Struct. Chem. 2015, 26, 1095.

https://doi.org/10.1007/s11224-015-0571-2

19. Li, C.; Li, D.; Ma, C.; Liu, Y. J. Mol. Liq. 2016, 224, 83.

https://doi.org/10.1016/j.molliq.2016.09.088

20. Li, H.; Yin, H.; Liu, X.; Shi, Y. J. At. Mol. Sci. 2016, 7, 115-124.

21. Mitchell, J.B.O.; Price, S.L. J. Comput. Chem. 1990, 11, 1217. https://doi.org/10.1002/jcc.540111014 
22. Charisiadis, P.; Kontogianni, V.G.; Tsiafoulis, C.G.; Tzakos, A.G.; Siskos, M.; Gerothanassis, I.P. Molecules 2014, 19, 13643.

https://doi.org/10.3390/molecules190913643

23. Taylor, R. Cryst. Growth Des. 2016, 16, 4165.

https://doi.org/10.1021/acs.cgd.6b00736

24. Desiraju, G.R. Acc. Chem. Res. 1996, 29, 441.

https://doi.org/10.1021/ar950135n

25. Alkorta, I.; Elguero, J. Chem. Soc. Rev. 1998, 27, 163.

https://doi.org/10.1039/a827163z

26. Rajput, A.P.; Rajput, S.S. Int. J. Pharm. Pharm. Sci. 2011, 3, 346.

27. Rani, K.M.; Rajendran, S.P. Int. J. Innovative Res. Sci. Eng. Technol. 2014, 3, 15966.

28. Venkanna, P.; Rajanna, K.C.; Satish Kumar, M.; Ansari, M.B.; Moazzam Ali, M. Tetrahedron Lett. 2015, 56, 5164.

29. Abonia, R.; Insuasty, D.; Castillo, J.; Insuasty, B.; Quiroga, J.; Nogueras, M.; Cobo, J. Eur. J. Med. Chem. 2012, 57, 29.

https://doi.org/10.1016/i.ejmech.2012.08.039

30. Kulkarni, P.; Swami, P.; Zubaidha, P. Synth. React. Inorg., Met.-Org., Nano-Met. Chem. 2013, $43,617$. https://doi.org/10.1080/15533174.2012.752392

31. Khan, K.; Siddiqui, Z.N. Appl. Organomet. Chem. 2014, 28, 789.

https://doi.org/10.1002/aoc.3200

32. Patil, C.B.; Mahajan, S.K.; Katti, S.A. J. Pharm. Sci. Res. 2009, 1, 11.

33. Moodley, T.; Momin, M.; Mocktar, C. Kannigadu, C., Koorbanally, N. A. Magn. Reson. Chem. 2016, 54, 610. https://doi.org/10.1002/mrc.4414

34. Alapour, S.; Farahani, M.D.; Silva, J.R.A.; Alves, C.N.; Friedrich, H.B.; Ramjugernath, D.; Koorbanally, N. A. Monatsh. Chem. 2017, 148, 2061.

https://doi.org/10.1007/s00706-017-2044-3

35. Gandhimathi, S.; Balakrishnan, C.; Venkataraman, R.; Neelakantan, M.A. J. Mol. Liq. 2016, $219,239$. https://doi.org/10.1016/j.molliq.2016.02.097

36. Alphonse, R.; Varghese, A.; George, L.; Nizam, A. J. Mol. Liq. 2016, 215, 387.

https://doi.org/10.1016/j.molliq.2015.12.050

37. Li, Q.; Li, B.; Liu, B.; Yu, M. J. Chem. Res. 2010, 34, 379.

https://doi.org/10.3184/030823410X12780936189898

38. Dulla, B., Vijayavardhini, S., Rambau, D., Anuradha, V., Rao, M., Pal, M. Curr. Green Chem. 2014, 1, 73. https://doi.org/10.2174/22133461114019990002

39. Meth-Cohn, O.; Narine, B.; Tarnowski, B. Tetrahedron Lett. 1979, 20, 3111.

https://doi.org/10.1016/S0040-4039(01)95334-1

40. Waghray, D.; Zhang, J.; Jacobs, J.; Nulens, W.; Basarić, N.; Meervelt, L.V.; Dehaen, W. J. Org. Chem. 2012, $77,10176$.

https://doi.org/10.1021/jo301814m

41. Gupta, S.; Shivahare, R.; Korthikunta, V.; Singh, R.; Gupta, S.; Tadigoppula, N. Eur. J. Med. Chem. 2014, 81, 359.

https://doi.org/10.1016/j.ejmech.2014.05.034

42. Pawar, S.S.; Koorbanally, N.A. Magn. Reson. Chem. 2014, 52, 279.

https://doi.org/10.1002/mrc.4062 
43. Lee, Y.R.; Kim, D.H. Synthesis 2006, 603.

https://doi.org/10.1055/s-2006-926294

44. Becke, A.D. J. Chem. Phys. 1993, 98, 5648.

https://doi.org/10.1063/1.464913

45. Lee, C.; Yang, W.; Parr, R.G. Phys. Rev. B: Condens. Matter Mater. Phys. 1988, 37, 785.

https://doi.org/10.1103/PhysRevB.37.785

46. Miehlich, B.; Savin, A.; Stoll, H.; Preuss, H. Chem. Phys. Lett. 1989, 157, 200.

https://doi.org/10.1016/0009-2614(89)87234-3

47. Orio, M.; Pantazis, D.A.; Neese, F. Photosynth. Res. 2009, 102, 443.

https://doi.org/10.1007/s11120-009-9404-8

48. Frisch, M.J.; Trucks, G.W.; Schlegel, H.B.; Scuseria, G.E.; Robb, M.A.; Cheeseman, J.R. Gaussian 09, 2009, Gaussian, Inc., Wallingford, CT, USA.

49. Dennington, R.D.; Keith, T.A.; Millam, J.M. GaussView 5.0. 8. 2008. Gaussian Inc. 